\section{A GIFT FROM THE FEDERAL GOVERNMENT: ADMINISTRATIVE WRITING: A WORKBOOK}

\section{Joan E. Pavlich \\ l'Universite de Sherbrooke}

Greg Larocque and Heidemarie MacLean

Public Service Commission of Canada, Language Training Program Branch

Commission de la fonction publique du Canada, Direction generale du program de la formation linguistique

The federal government's excellent English course, Administrative Writing, is ready for distribution this summer. A companion to the French course, Rédaction Administrative (reviewed in Technostyle, Vol. 2, No. 2, Summer 1983), the English version comes as an efficient, easy-to-use 300 page workbook designed to polish the writing skills needed by civil servants. "Administrative Writing" is the term commonly used by the government, and by English and French universities in Ottawa, Montreal and Quebec City in place of the more general term "business writing."

Note that the course is for Québecois. A product of the federal bilingualism policy established in the lace 1960's and 1970's, this is an English as a Second Language program created and taught by Linguistic Services to ensure that French speaking civil servants have the opportunity to train in their other language. Such students are not the average learners who typically enter E.S.L. classes, but educated francos who already command basic English. Hence the course is not about everyday English; rather, as the introduction says, it is "aimedat a select group of professtonals who want practice in and perfection of specific elements of business correspondence."

This special aim makes the workbook valuable to anyone teaching business writing in Canada. The E.S.L. label is somewhat of a misnomer; here is a mature, English, business course presenting descriptions, short reports, memos, letters, rêsumés, etc. through precise definitions, practical examples, and numerous exercises. French is the subject of only one unit, "Faux Amis," a mere 5 pages drilling typical mistakes francophones make in vocabulary and word order, for example:

1. I ignore why the proposal was rejected.

2. Our Unit very much likes that idea.

It is worth remembering that Rédaction Administrative, though conceived or iginally for anglos, has always been used by both language groups, anglos to develop their bilingualism and francos to practice their writing skills. Similarly, Administrative Writing can serve both groups; Indeed, because it has been:

*revised of ten after extensive classroom trials

* streamlined to 1 volume (instead of the 8 French volumes)

*organized as an almost self-programmed workbook

${ }^{\star}$ given an estimated price around $\$ 10.00$ (exact $\cos t 1 \mathrm{~s}$ as yet unannounced)

It is an outright gift to teachers of English business writing.

Sensibly, the course begins with a "Basic Writing Review" of words, sentences and inter-sentence connectlons, organized so that teachers supervise only and students do all the work. "Focus on Words," for example, has firm opening directions: "Because the treatment is so limfted and each element is so clearly focussed, students should achieve $80 \%$ accuracy or better if they are to consider they have sufficiently mastered each unit. Students should refer to other texts if they feel they would like more work on a particular element." Then it divides the study of words into five units--prepositions, capitalizing, adjectives, adverbs, vocabulary development--and then provides 20 pages of differing exercises, each with an answer key.

Despite the disclaimer, the Review covers many fundamentals well. Perhaps this is where the authors' backgrounds in second language teaching contribute most (Mr. Larocque presently heads the T.E.S.L. organization In Ontario). For instance, everything is so markedly Canadian and therefore refreshingly different from the American milleu throughout the imported texts we are usually given. It just is easier to teach the comma with sentences like:

1. This applicant has applied for vacancies at Statistics Canada Canada Post Trade and Commerce and Health and Welfare.

2. The second Prime Minister the Right Honourable Louis Joseph Papineau was born in the province of Quebec. 
The exercises are consistently practical. Sentences do not slip in references to literature, express emotion, become conversational or use adolescent vocabulary; rather they emphasize at all times simple, clear communication of information. The following example shows how an exercise can be programmed (answer key included), introduce a complicated topic (parallelism and gerunds), foster classroom discussion (with another student/teacher), and still be businesslike:

\section{CHOOSING THE BEST ANSWER}

Complete the sentences below by selecting the most appropriate answer. Each correct answer must have parallel gerund constructions. Work alone and exchange your final choices with another student; be prepared to justify your answers. Consult the teacher on any discrepancies.

1. Controllers coming on duty are responsible for

a) to sign the duty roster on arrival, to inform the supervisor of their arrival, and immediately to take control of their posts.

b) that signing the duty roster on arrival, informing the supervisor of their arrival, and immediately taking control of their posts

c) signing the duty roster on arrival, informing the supervisor of their arrival, and immediately taking control of their posts

d) they sign the duty roster on arrival, they inform the supervisor of their arrival, and they imediately take control of their posts

The Revlew concludes by studying the flve paragraphs most necessary in business writing:

1. Describing a situation

2. Describing a process

3. Describing what happened (chronology)

4. Describing cause and effect situations

5. Comparing and contrasting

in 30 pages of admirable, practical exercises. How can paragraph writing be programmed? Note the following:

\section{DESCRIBING THE STATE OF TRAINING ALLOCATIONS FOR 1987}

In the illustration bolow, you will find come Organised Information. Below that you will find a Longrage Key. Study the Information carefully. Then, coneulting the Language Iey urite a Pirest Draft of your Deseribing Paragraph. Show the Draft to your Teacher for possible improvements. Using these improvemente, write a Pinal Draft .

\section{argonised Information}

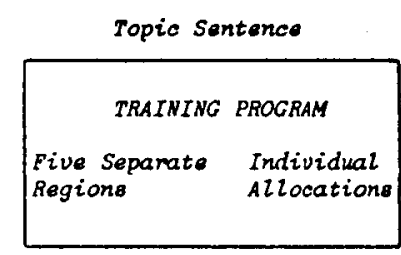

Detaile
\begin{tabular}{c} 
ATLANTIC \\
$\$ 295,000(09 / 83)$ \\
ONTARIO \\
$\$ 183,000(09 / 83)$ \\
QUEBEC \\
$\$ 457,000(10 / 83)$ \\
PRATRIE \\
$\$ 283,000(11 / 83)$ \\
PACIPIC \\
$\$ 287,000(i 1 / 83)$ \\
\hline
\end{tabular}

Conclusion

\begin{tabular}{|cc|}
\multicolumn{2}{|c|}{ TRAINING PROGRAM } \\
$\begin{array}{ll}\text { Five Separate } & \text { Total } \\
\text { Regione } & \text { Allocation } \\
& \$ 1,505,000\end{array}$ \\
\hline
\end{tabular}

Longrage Xey

\begin{tabular}{|c|c|c|}
\hline $\begin{array}{l}\text { Posaible Connectors } \\
\text { and (also, } 60 . . .) \text {, also too, } \\
\text { or, but (also...), in addi- } \\
\text { tion (to...), as well ras...), } \\
\text { besides, moreover, furthemore }\end{array}$ & $\begin{array}{l}\quad \text { Possible Stmuctures } \\
\text { there ia/are..... } \\
\text { there seema(s) (infinitive) } \\
\text { adjectives } \\
\text { past/present participles } \\
\text { past/present oimple tense } \\
\text { passive woice }\end{array}$ & $\begin{array}{c}\text { Posaible Vocabulary } \\
\text { N.- staff, professionul } \\
\text { development, } \\
\text { course(s), training, } \\
\text { expenditure(s) } \\
\text { Adj,- "in house", apdit- } \\
\text { able, geographic, } \\
\text { projected } \\
\text { Verb-to sponsor, to fund, } \\
\text { to supply, to faci- } \\
\text { litate, to respond, } \\
\text { to demand, to } \\
\text { improve } \\
\text { Adv.-readily, very }\end{array}$ \\
\hline
\end{tabular}

Such drills lead finally to more demanding exercises, always 111 ustrating practical writing. Here, for instance, is basic process 
DESCRIBING THE PROCESS OF A MACHINE IN YOUR UNIT

You are very knowledgeable about how a particular machine in your office operates (i.e. micro computer, word processor, electric typewriter with memory capacity). Many of the new staff seem unable to operate this machine, and your Supervisor has asked you to write a operate this machine, and your Supervioo

After selecting the machine you know best, write a description of the operating process. Once you have finished the Final Draft, give it to another student to read. Allow the other student to coment on how clear your description was and how it could be improved.

The next two sections of the course use the paragraph in the writing of memos and letters, then the concluding section pulls everything together by teaching students to write a professional curriculum vitae.

The discussion of memos is a delight. One assumes the government veritably breathes memos and indeed these 43 pages reflect that expertise. In small, every question about form is clarified, for example, dates:

\section{ABBREVIATED FORM}

Both the month and the year may be abbreviated as follows:
Aug. 23, 84
Aug. 23/84
23 Aug. 84

Altermatively, it is also acceptable to use only numbers to represent the date. Canadian usage is to write the day first, then the month and then the year. Some examples follow.
$23 / 8 / 84$
$23 / 08 / 84$
$23-8-84$

Note: Since 1976, the Canadian Standards Association has suggested writing dates with the year in four digits first, then the month in two digits and finally the day in two digits. The above example would then be written as follows:

$1984-08-23$
Routine parts of a message are defined and drilled, often with subtlety:

\section{INDICATING UNDERSTANDING OF A PROBLEM}

The expressions below reassure the reader that the writer knows about and understands some difficulty that exists. As such, these expressions serve a positive function. Nevertheless, they are frequently used as a prelude to unpleasant information.
It is understood...
I (can) realize/understand...
It is fully appreciated..
We recognize/appreciate...
It is recognized..

\section{EVALUATING THE INTENT OF EXPRESSIONS (Answer key included)}

Read the following sentences and decide whether these expressions serve a) only to reassure, or b) to reassure and to lead into some disagreeable information. Discuss with members of the class.

1. Though I realize that a memo has already been sent, I am afraid another one will have to be issued.

2. While I understand that this is only a minor item, I would appreciate your rectifying the matter as soon as possible.

3. We wish to congratulate you on your excellent efforts on our behalf. Please be assured that we recognize how difficult it is to please all of the people all of the time.

etc.

\section{IN YOUR OPINION...}

How are the standard expressions modified to signal the reader that unpleasant information is coming? What is the difference in meaning between: 
In large, $17 \mathrm{kinds}$ of memos are identifled and drilled with exercises like:

\section{EDITING AND REWRITING}

Belaw you will find a memo which needs improvement. Using the "Suggestions" given, rewrite the memo to a more acceptable form. Remember to vary your constructions. Show your finished memb to your teacher or another student for comments.

\begin{tabular}{|c|c|}
\hline To: & $\begin{array}{l}\text { Public Service Alliance of Canada Members } \\
\text { Education Group }\end{array}$ \\
\hline Prom: & President, P.S.A.C. \\
\hline Subject: & $\begin{array}{l}\text { Response to Anti-Inflation Act Guidelines } \\
\text { The guidelines to the Anti-Inflation Act were issued } \\
\text { on September } 18 \text {, } 1982 \text {. In general, increases in excess of the } \\
\text { guidelines may be permitted if the group is entitled to } \\
\text { special consideration or if the group has an historical } \\
\text { relationship with another group. }\end{array}$ \\
\hline & $\begin{array}{l}\text { We had hoped that we would be entitled to special } \\
\text { consideration for the ED group since we had signed a } \\
\text { collective agreement prior to January } 1,1983 \text {, however, all } \\
\text { rates of pay were increased on April 1, } 1982 \text {, by S500, and } \\
\text { the Anti-Inflation Board has already refused to recognias } \\
\text { special consideration in similar circumbtances. In the recent } \\
\text { postal dispute, the AIB stated in its decision that the } \\
\text { collective agreement was "substantially" modified on April 1, } \\
1982, \text { by increasing all rates by \$500. That same decision } \\
\text { will undoubtedly apply to the ED group. }\end{array}$ \\
\hline & $\begin{array}{l}\text { We can prove that an historical relationship exists } \\
\text { between federal teachers and their provincial counterparts. } \\
\text { Rates of pay for the EST subgroup have always been negotiated } \\
\text { on the basis of comparisons of federal rates of pay with those } \\
\text { of teachers in the provincial sector. The resulting overall } \\
\text { payroll increase granted to the EST sub-group has always been } \\
\text { granted to the LAT and EDS sub-groups. We will continue to } \\
\text { negotiate on that basis. }\end{array}$ \\
\hline & $\begin{array}{l}\text { We do not know if Treasury Board is prepared to recognize } \\
\text { this historical relationship and table wage offers in excess of } \\
\text { the guidelines. You can be assured that your negotiating team } \\
\text { will continus on the basis of this relationship. }\end{array}$ \\
\hline
\end{tabular}

\section{Suggestions:}

1. Shorten the memo to about half its present length; it's much too wordy.

2. The first sentence of paragraph 2 is a run-on. Condense it.
3. Use appropriate connectors to link sentences to each other, especially in paragraph 3 .

College students find business letters difficult (probably moreso than civil servants, who at least read them constantly). Hence this section, with the same attention to deta11, efficient programming and fine writing/editing exercises, wlll be particularly welcome to teachers. The subsequent exercise speaks for itself:

\section{REGRETTING}

On occasion, you may not be able to be of assistance to someone who has written to you. Read the letter to see how someone else in a similar situation responded.

Dear Ms. Proctor:

This acknowledges your letter of April 4, in which you made enquiries about a position calling for experience in commercial art.

Unfortunately, the work of this office is connected with the promotion of industrial design and entails specialties which call for many years of experience in environmental, engineering or industrial design.

we do not rule out the possibility that your talents may be in demand elsewhere in government. With this in mind, may we suggest that you write the Public Service Commission in Ottawa, outlining in detail your education, experience and interests. We are enclosing the Public Service application form for this purpose.

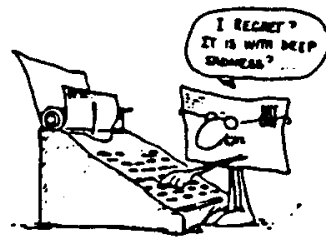

May I take this opportunity to thank you for your interest in a government career and wish you every success in your application.

NOTE: This is a very polite response to what is really a "nuisance" letter from the point of view of the department; that is, someone must take the time to respond to Ms. Proctor - even though they cannot use her services - and politely tell her so.

\section{IN YOUR OPIXIOR...}

To gain an understanding of why this letter is polite, go through it and answer the following questions:

1. What purpose does the writer accomplish in each paragraph? 
2. Why could the letter not begin with the second paragraph?

3. Is the last paragraph essential? Why was it included?

4. How would Ms. Proctor have felt

a) if the second paragraph had started, "We suggest you restrict your aplications to positions which call for the kind of experience you are able to offer";

or

b) if ahe had received no conswer at all to her letter?

Mrs. Proctor's letter follows the pattern below:

$\begin{gathered}\begin{array}{c}\text { ACKNOWLEDGEMENT } \\ \text { Para. } 1\end{array} \\ \text { Para. 2 }\end{gathered}+\begin{aligned} & \text { REGRET } \\ & \text { PELPFUL INFORMATION/SUGGESTION } \\ & \text { Para. } 3\end{aligned}+\begin{aligned} & \text { THANKING } \\ & \text { Para. } 4\end{aligned}$

The Anderson letter below follows the slightly different pattern of

$\begin{gathered}\text { ACKNOWLEDGEMENT } \\ \text { Para. } 1\end{gathered}+\begin{gathered}\text { REGRET/MELPFUL INFORMATION } \\ \text { Para. } 2\end{gathered}$

Dear Mr. Anderson:

This will acknowledge receipt of your recent letter requesting a list of printers' names.

I regret that I am unable to send you a list of names, but for your information, 1 am enclosing a list of reliable printing companies that may te of assistance to you.

\section{IN YOUR OPINION...}

1. Is the Anderson letter as gracious as the Proctor one? Is there any need for it to be?

2. How are the two letters different?

The Curriculum Vitae occuples only 9 pages, and justifiably so,

since its parts are easily defined and 1llustrated. The workbook's presentation here is much like those in ordinary texts.

A conclusion: There are shortcomings. Teachers may find the assumption that students work In a government Unit Irritating at times and obviously will miss discussion of long, formal reports. C'est la vie, no text is flawless.
LE METIER DE CORRECTEUR: L'ART DE VIVRE SELON LE DICTIONNAIRE

Sylvie Laferriere

Lorsqu'un enfant de $s i x$ ans trace les premlers signes de son alphabet sur les lignes de son cahter d'écoller, 11 ne sait pas encore tout le chemin qu'il aura à parcourir pour exprimer sa pensée dans un langage clair et conc1s. Il tgnore la place assignée à chaque mot, les angolsses de l'analyse grammaticale, les règles, souvent complexes, de la grammalre et surtout, il ne connaft pas la signification du mot "EXCEPTION". Peu lui importe le style, le rythme de la phrase, les Impropriétés, le particlpe passé avec ou sans auxillaire, le pluriel des noms composés. Pour luí, l'emplol de la majuscule ou de la minuscule, dans un texte, est un point d'interrogation. Ses figures de style sont plutôt géométriques; 11 les trace avec application.

Puis, l'étudiant découvre avec étonnement qu'une phrase peut devenir incompréhensible si elle n'est pas bien formulée, équivoque si l'on omet ou déplace une virgule; que la langue française obéft à certaines normes et qu'elle piège souvent celui qui cherche à l'écrire avec le plus de clarté possible.

Lors de la rédaction d'un texte, 11 s'arrête, hésitant sur l'orthographe d'un mot et ne salt plus très bien où placer sa virgule. A la page trois cent quatre-vingt-selze de son dictlonnalre Robert, au mot correcteur, 11 11t: "Personne qui corrige en relevant les fautes et en jugeant".

Vollà. Le métier que f'essaie d'exercer ne tient qu'une ligne dans les pages du dictionnaire et guère plus dans l'esprit des gens. Pourtant, chacun de nous peut retrouver, dans sa mémoire, l'Image d'un professeur de frança1s qui soulignait d'un trait rouge les fautes sur la page blanche de nos feutlles d'examen.

La correction de textes est une activité méconnue. Elle se pratique le plus souvent dans l'ombre d'un bureau, anonyme. Où trouve-t-on le nom du correcteur dans les premtères pages d'un livre? 